\title{
MADRASAH
}

Jurnal Pendidikan dan Pembelajaran Dasar

p ISSN: 1979-5599 | e ISSN: 2502-194X

P a g e | 173

\section{Studies on the Ecological Competence of Civic Education in Primary Schools}

\section{Kajian Kompetensi Ekologi Pendidikan Kewarganeraan di Sekolah Dasar}

\author{
Yoga Ardian Feriandi ${ }^{1}$, Dasim Budimansyah' ${ }^{2}$, Kokom Komlasari ${ }^{3}$ \\ 1,2,3Universitas Pendidikan Indonesia/ Jalan Dr Setiabudhi No 229 Bandung Indonesia, \\ (022-2013163) \\ 1yogaardian@upi.edu, 2budimansyah@upi.edu, $\underline{3 \text { kokom@upi.edu }}$
}

DOI: $\underline{10.18860 / \mathrm{mad} . v 13 i 2.12291}$

Abstract. The development of the world of technology has provided many changes in the pattern of human life, including influencing environmental phenomena that have an impact on the way of life of citizens. To prevent environmental destruction. So ecological education is one of the efforts to continue the effort to create citizens who care about the environment with their environmental characteristics. This study aims to examine the ecological competence of elementary school students through civic education in building awareness of the environment. The approach used in this research is qualitative with the literature study method. The results of the analysis and study in this study indicate: 1) the competence of knowledge and ecological strategies of elementary school students is formed through civic education, 2) elementary school students can act on environmental issues, 3) elementary school students have the quality to address environmental issues through civic education. So that the conclusion in this study is that the ecological competence of elementary school students can be formed through civic education, the output of which is that these students have environmental skills and character in utilizing their environment.

Keywords. Ecological Competence; Citizenship Education; Elementary School

\begin{abstract}
Abstrak. Perkembangan dunia teknologi telah memberikan banyak perubahan dalam pola hidup manusia, termasuk juga memberikan pengaruh terhadap adanya fenomena lingkungan yang berdampak pada cara hidup warga negara. Sehingga untuk mencegah terjadinya perusakan lingkungan. Maka pendidikan ekologi merupakan salah satu upaya dalam meneruskan usaha menciptakan warga negara yang peduli lingkungan dengan karakter lingkungan yang dimilikinya. Penelitian ini bertujuan untuk mengkaji kompetensi ekologi siswa sekolah dasar melalui pendidikan kewarganegaraan dalam membangun kepedulian terhadap lingkungan. Pendekatan yang digunakan dalam penelitian ini ialah kualitatif dengan metode studi literatur. Hasil analisis dan kajian pada penelitian ini menunjukkan: 1) kompetensi pengetahuan dan strategi ekologi siswa sekolah dasar terbentuk melalui pendidikan kewarganegaraan, 2) siswa sekolah dasar memiliki kemampuan untuk bertindak tentang isu lingkungannya, 3) siswa sekolah dasar memiliki kualitias untuk menyikapi isu lingkungan melalui pendidikan kewarganegaraan. Sehingga kesimpulan dalam penelitian ini ialah, kompetensi ekologi siswa sekolah dasar dapat terbentuk melalui pendidikan kewarganegaraan, yang
\end{abstract}


output-nya siswa tersebut memiliki keterampilan lingkungan dan karakter dalam memanfaatkan lingkungannya.

Kata Kunci. Kompetensi Ekologi; Pendidikan Kewarganegaraan; Sekolah Dasar

Received: 29-05-2021

Revised: 10-06-2021
Approved: 18-06-2021

Published: 30-06-2021

Copyright (C) Madrasah Jurnal Pendidikan dan Pembelajaran Dasar. All Right Reserved. This is an open access article under the CC BY-SA license

(Creative Commons Attribution-ShareAlike 4.0 International License.)

Correspondence Address: yogaardian@upi.edu

\section{A. PENDAHULUAN}

Lingkungan merupakan anugerah yang diberikan oleh Tuhan yang Maha Esa kepada manusia untuk dijaga, dilestarikan dan diindahkan adanya. Persoalan lingkungan sudah menjadi masalah yang kompleks yang sering terjadi dalam berbagai macam aspek kehidupan kita, dan sudah merambat dan mengakar masuk kedalam ranah pendidikan (Sagala, Nuangchalerm, Saregar, \& El Islami, 2019). Di dalam pendidikan, istilah menjaga lingkungan disebut dengan karakter peduli lingkungan. Kepedulian lingkungan ini merupakan suatu kecerdasan yang dimiliki oleh warga negara dalam mengaplikasikan pengetahuan yang dimilikinya dalam kehidupan lingkungannya.

Kemajuan teknologi yang dianggap sebagai sarana untuk mempermudah kehidupan manusia juga dapat menjadi sumber persoalan dalam hidup manusia, misalnya berkurangnya kualitas udara bersih akibat alat transportasi, perusakan lingkungan dengan kemajuan teknologi pembajak sawah, penebangan hutan dan lainlain. Dengan demikian, kemajuan teknologi dapat memberikan dampak positif dan negatif dalam kehidupan manusia. Pernyataan di atas dibuktikan oleh adanya penelitian yang dilakukan oleh Karsten, S. (1998) dan Cogan (1983). Penelitian tersebut menunjukkan bahwa kemajuan teknologi dapat memunculkan fenomena yang berdampak pada kehidupan warga negara mulai dari bertambahnya jumlah penduduk, berkurangnya air bersih, mahalnya udara bersih, polusi lingkungan dan adanya senjata nuklir yang menghancurkan keindahan lingkungan. Kerusakan alam tersebut juga diperparah dengan adanya peraturan hukum maupun produk politik yang salah dan tidak mempertimbangkan pembangunan berkelanjutan sehingga membuat kerusakan lingkungan semakin merajalela (Budimansyah, Fitriasari, Iswandi, Muthaqin, \& Insani, 2021; Zhang, Tan, \& Chan, 2020).

Pembentukan kompetensi ekologi melalui Pendidikan Kewarganegaraan merupakan usaha sadar dan terencana yang dilakukan oleh lembaga formal untuk membentuk karakter dan kompetensi warga negara yang cinta dan peduli terhadap lingkungannya. Sehingga, melalui ini, pelestarian lingkungan akan membentuk keterampilan warga negara dalam menjaga anugerah yang telah diberikan oleh Tuhan (A. Dobson, 2007), lingkungan, yang berkaitan dengan berbagai aspek seperti politik, hukum, teknologi, maka salah satu jalan yang dianggap tepat untuk menyelesaikan permasalahan ini yakni melalui pendidikan (Berkowitz, Ford, \& Brewer, 2005; Andrew Dobson, 2007; Krasny et al., 2015; Latta, 2007; Quinn, Castéra, \& Clément, 2016; 


\section{MADRASAH}

Jurnal Pendidikan dan Pembelajaran Dasar

p ISSN: 1979-5599 | e ISSN: 2502-194X

P a g e | 175

Valencia Sáiz, 2005; Wolf, Brown, \& Conway, 2009). Salah satu mata pelajaran yang dianggap cocok yakni Pendidikan Kewarganegaraan, karena merupakan mata pelajaran dengan bidang kajian yang bersifat Multifacet dengan konteks lintas bidang keilmuan (Wahab \& Sapriya, 2011: 95). PKn memiliki objek kajian konsep demokrasi politik untuk hak dan kewajiban warganegara yang diharapkan mampu memunculkan penalaran kewarganegaraan (Civic Knowledge), sikap kewarganegaraan (Civic Dispotition), keterampilan kewarganegaraan (Civic Skills), komitmen kewarganegaraan (Civic Commitment) dan kemampuan kewarganegaraan (Civic Competence) (Wahab \& Sapriya, 2011: 97). Pemberian pendidikan tentang lingkungan melalui pendidikan kewarganegaraan juga akan membantu membentuk siswa dalam merumuskan sesuatu yang baik untuk dilakukan dan yang tidak baik untuk dilakukan olehnya, pemberian pendidikan ekologi tidak hanya dilakukan pada orang dewasa saja, tetapi pembentukan karakter ekologi juga perlu dilakukan pada usia siswa sekolah dasar.

Jika dikaji pada subjek dan objek penelitiannya, siswa sekolah dasar belum secara matang memiliki pemahaman tentang konsep menjaga lingkungan, serta belum terbentuk kesadaran dalam menciptakan kondisi lingkungan yang bersih, kesadaran tersebut juga termasuk kedalam kesadaran untuk menguasai dirinya, mengontrol hidup sehatnya, juga mengatur lingkungannya agar sesuai dengan cerminan gaya hidup sehat dan menjaga kelestarian lingkungannya (Sukma, Ramadhan, \& Indriyani, 2020), untuk itu siswa perlu untuk ditumbuhkan tanggung jawab mengenai kelestarian lingkungan, dan melihat kelestarian lingkungan sebagai persoalan global (Berkowitz et al., 2005; Scoville, 2016) yang selanjutnya kompetensi ini sebut sebagai ecological citizenship.

Dalam hal ini, peran guru sangatlah penting sebagai sarana pembentukan kompetensi ekologi siswa melalui pendidikan kewarganegaraan, guru sebagai pelaku utama pendidikan memiliki peran dalam memberikan nilai dan konsep tentang pendidikan ekologi untuk menjaga kelestarian lingkungan. Berbicara tentang upaya pemberian pendidikan ekologi pada siswa, pada dasarnya bahwa persoalan lingkungan merupakan bagian dari isu dunia yang perlu mendapatkan pendekatan dan penangan yang sesuai, sehingga pendekatan pembelajaran ekologi pada siswa perlu diintegrasikan kedalam perangkat pembelajaran sebagai usaha untuk penanaman nilai lingkungan hidup di sekolah dan di masyarakat (Pertiwi \& Samsuri, 2017; Wahyuningtiyas, 2016). Sehingga untuk memperkuat hasil kompetensi ekologi yang diharapkan, guru harus secara ektra bekerjasama dengan orang tua, dan pemangku kepentingan bidang pendidikan lainnya. Tujuan utamanya agar pemahaman siswa tentang pendidikan ekologi tidak hanya sebatas konsep didalam kelas saja, tetapi mampu diterapkan dan diaplikasikan dengan baik dalam lingkungan tempat ia tinggal sebagai perwujudan warga negara yang memiliki tanggung jawab terhadap lingkungan sosialnya.

Dalam konteks tersebut, pemerintah telah melakukan berbagai upaya dalam melestarikan lingkungan dan salah satunya ialah melalui peraturan dan konstitusi yang berperan sebagai landasan perlindungan yang bersifat hukum. Oleh karena sifat manusia yang tidak pernah mengindahkan suatu aturan, maka pembentukan pencegahan perusakan lingkungan perlu disuntikkan ke dalam nuansa pendidikan. Salah satunya yaitu pemberian pendidikan kepedulian lingkungan pada usia sekolah

Vol. 13 No. 2 Juni 2021

Madrasah homepage: http://ejournal.uin-malang.ac.id/index.php/madrasah/index 
dasar (Feriandi, 2018).

Hal di atas diperkuat oleh adanya pernyataan yang mengatakan bahwa, untuk meningkatkan kepedulian masyarakat dan membentuk kepribadiannya yang memiliki kebajikan maka pendidikan memiliki peran penting dalam proses itu (Thomas Lickona, 2012). Untuk itu, sesuai dengan tujuan dari pendidikan kewarganegaraan itu sendiri, pola pembentukan sikap dan karakter warga negara dapat dilakukan dalam sekolah formal demi membentuk warga negara yang cerdas, tanggung jawab, serat peduli pada lingkungannya (Wahab \& Sapriya, 2011).

Pendidikan kewarganegaraan dalam menjalankan visinya tidak hanya memegang peran membentuk warga negara yang taat dan melaksanakan hak dan kewajibannya sebagai warga negara saja tetapi memiliki Keterkaitan pendidikan kewarganegaraan dengan pendidikan ekologi ialah dalam membentuk kompetensi siswa untuk memiliki kesadaran dalam menjaga lingkungannya. Permasalahnya di sekolah dasar pendidikan lingkungan diajarkan secara teoritis dan kurang menyentuh aspek perilaku, padahal idealnya pendidikan mengenai lingkungan harus menyentuh ketiga aspek utama yakni pengetahuan, keterampilan, dan sikap (Sukma et al., 2020). Hal ini dibuktikan oleh adanya penelitian (McBride, B. B., Brewer, C. A., Berkowitz \& R., \& Borrie, 2013) tentang environmental literacy, ecological literacy, ecoliteracy yang menghasilkan bahwa masalah lingkungan merupakan bagian dari moralitas manusia yang perlu diatur untuk keberlangsungan hidup manusia, karena akan berhubungan dengan kesadaran manusia dalam membentuk pengetahuan dan karakter lingkungannya.

Sebenarnya telah ada beberapa kajian lain yang membahas mengenai pembentukan kesadaran lingkungan melalui mata pelajaran Pendidikan Kewarganegaraan seperti Berkowitz et al. (2005), McBride, B. B., Brewer, C. A., Berkowitz \& R., \& Borrie (2013) yang membahas bagaimana mengintegrasikan karakter perduli lingkungan, pengetahuan kewarganegaraan tentang lingkungan kedalam bentuk pendidikan untuk lingkungan hidup, sayangnya dalam kajian ini tidak secara spesifik menjelaskan bagaimana pengintegrasianya dalam ranah sekolah dasar. Kajian lain yang lebih baru misalnya dilakukan oleh Karatekin \& Uysal (2018) berhasil mengembangkan ukuran/skala untuk menilai tingkat ecological citizenship pada seorang warga negara, namun sayangnya ukuran warga negara yang digunakan adalah warga negara dewasa yang tentu berbeda dengan calon warga negara yang saat ini masih berada dalam lingkup sekolah dasar. Oleh karena itu, rumusan masalah dan tujuan dalam penelitian ini akan mencoba mengambil titik pembeda pada permasalahan yang bersifat lebih praksis dan terkait dengan sekolah dasar, karena pembentukan karakter maupun kompetensi lingkungan tentu akan lebih baik apabila telah dimulai sejak dini ketika siswa ada di sekolah dasar. Dengan demikian penelitian ini akan membahas upaya guru dalam membentuk kompetensi kewarganegaraan ekologi melalui pendidikan kewarganegaraan di sekolah dasar.

\section{B. METODE PENELITIAN}

Penelitian ini menggunakan pendekatan kualitatif dan metode studi literatur. Creswell mengatakan bahwa penelitian kualitatif merupakan suatu penelitian yang meneliti dan memhami suatu fenomena dan maka suatu individu dan kelompok orang yang berasal dari masalah sosial (Creswell, 2016). Sedangkan studi literatur merupakan suatu penelitian yang dilakukan oleh seseorang atau kelompok dengan menganalisis

Vol. 13 No. 2 Juni 2021

Madrasah homepage: http://ejournal.uin-malang.ac.id/index.php/madrasah/index 


\section{MADRASAH}

Jurnal Pendidikan dan Pembelajaran Dasar

p ISSN: 1979-5599 | e ISSN: 2502-194X

jurnal, buku dan lain sebagainya dengan tujuan untuk mengungkapkan teori yang berhubungan dengan masalah yang akan diteliti (Danial \& Wasriah, 2009).

Sehingga dalam penelitian ini, studi literatur merupakan metode yang dianggap sesuai untuk menunjang hasil temuan yang didapatkan oleh peneliti, sebagai cara yang tepat dan sesuai untuk menganalisis fenomena dalam persoalan penelitian. Jenis literature review yang digunakan dalam penelitian ini yakni semantic review, alasan pemilihan semantic review sendiri dikarenakan model penelitian literature review untuk ilmu sosial dikatakan lebih cocok untuk semantic review (Snyder, 2019), karena dalam prosesnya mampu mengali dan membandingkan serta mengelaborasi berbagai teori dan temuan dari penelitian lainya. Langkah dalam penelitian ini terdiri dari melakukan penelusuran dan pencarian data, pemilihan data yang akan digunakan, melakukan review dari berbagai data yang telah dipilih, dan pada tahap yang terakir dilakukan analisis untuk menjawab permasalahan penelitian (Dwi Mustikarini \& Feriandi, 2020).

\section{HASIL DAN PEMBAHASAN}

\section{a. Membangun Kompetensi Ekologi Siswa}

Kompetensi ecological citizenship dalam penelitian ini yakni merupakan seperangkat kompetensi dasar warganegara yang berguna untuk menjaga kelestarian lingkungan. Beberapa kompetensi ini yakni, mampu menganalisis kebijakan lingkungan hidup, berperan dalam gerakan sadar lingkungan, menjadi warganegara yang aktif berpartisipasi dalam menjaga kelestarian lingkungan dan memandang kelestarian lingkungan secara makro (Dobson, 2007). Berdasarkan hasil analisis dan kajian yang dilakukan oleh peneliti. Dalam usaha untuk membentuk kompetensi ekologi warga negara melalui pendidikan kewarganegaran di sekolah yang pertama yang dapat dilakukan oleh guru di sekolah ialah, dengan mengintegrasikan nilai peduli lingkungan kepada setiap perangkat pembelajaran sebagai upaya pencapaian kompetensi ekologi pada siswa sekolah dasar.

Tentu tidak semua kompetensi tersebut bisa tertanam pada usia anak sekolah dasar, tetapi dasar-dasar untuk mencapai kompetensi tersebut tentulah harus sudah mulai di tanaman kan sejak usia dini. Penanamkan kompetensi tersebut misalnya bisa dilakukan melalui keteladanan dari guru (Thomas Lickona, 2012). Kemudian, guru dapat menggunakan strategi pembelajaran dengan melakukan pola pembiasaan hidup bersih, dan keteladanan yang ditampilkan oleh guru kepada siswa. Sehingga menurut Mulyasa bahwa keteladanan merupakan bentuk pembiasaan perilaku dan kepribadian yang dilakukan dalam kehidupan sehari-hari, serta guru dapat berperan sebagai tauladan karna sifat manusia pada dasarnya suka mencontoh apa yang dilihatnya secara langsung dan tidak langsung (Mulyasa, 2014).

Oleh karena itu pola perilaku siswa akan tercermin apabila dilakukan pada pembiasaan setiap hari, misalnya guru dan siswa dapat menyepakati suatu aturan apabila terdapat siswa yang membuang sampah bukan pada tempatnya akan diberikan berupa sanksi. Kemudian hasil lain dalam penelitian ini ialah terbentuknya kompetensi ekologi melalui pendidikan kewarganegaraan yaitu pertama terbentuknya pengetahuan siswa tentang isu lingkungan dan ia mampu menyusun pengetahuan tersebut sebagai suatu strategi siswa dalam bertindak, kedua terbentuknya kompetensi untuk menyikapi strategi dan pengetahuan tentang isu lingkungan yang dimilikinya, ketiga memiliki 
sikap yang berkualitas dalam menyikap isu lingkungan.

Kompetensi ekologis merupakan sesuatu hal yang penting yang harus dibentuk dalam diri siswa, yang berkaitan dengan pemahaman dan kesadaran siswa untuk mempelajari lingkungannya (Yunansah \& Tri Herlambang, 2017). Sehingga kompetensi ekologis merupakan indikator pertama yang harus di integrasikan kedalam mata pelajaran khususnya PKn karna melalui ini siswa dilatih untuk mengembangkan dirinya. Berbicara mengenai upaya sekolah dalam membangun kompetensi ekologis siswa, guru diharapkan mampu merancang pembelajaran yang berinovasi yang didalamnya terdapat pesan moral yang mengingatkan bahwa sosa memiliki keterikatan dengan alam.

Selanjutnya dalam teorinya, Palmer (2015) mengatakan bahwa kompetensi ekologis terdiri dari pembentukan pola pengetahuan, pemahaman dan keterampilan yang termuat didalamnya tentang partisipasi seseorang dalam lingkungan. Sehingga berdasarkan teori ini, bahwa usaha sekolah dalam membangun kompetensi ekologis siswa tidak hanya sebatas konsep saja, tetapi juga pada kemampuan siswa dalam mengaplikasikannya dalam lingkungannya tempat tinggal. Sehingga keterampilan ini disebut sebagai partisipasi ekologis siswa. Oleh karena itu, menurut A. Dobson (2007) untuk mendukung kelestarian lingkungan, terbentuknya watak peduli lingkungan tidak hanya dapat berupa pengetahuan saja, melainkan harus dijadikan sebagai sebuah kebiasaan. Apabila terjadi masalah lingkungan yang berkaitan dengan perilaku warga negara, hal itu perlu diintegrasikan ke dalam disiplin ilmu pendidikan kewarganegaraan dan menjadi kompetensi yang disebut ecological or enviromental citizenship.

Selanjutnya Dobson juga menjelaskan bahwa karakteristik enviromental citizenship bahwa setiap warga negara memiliki hak yang sama, kewajiban dan tanggung jawab dalam menjaga lingkungan (A. Dobson, 2007). Sehingga dalam penelitian (Feriandi, 2018) tentang Konfigurasi Pendidikan Kewarganegaraan Ekologi Perspektif sosio-kultural (Gagasan Pembentukan Pendidikan Kewarganegaraan Kontium Maksimal di Indonesia), mengatakan bahwa melalui enviromental citizenship dalam pendidikan kewarganegaraan diberikannya kesempatan kepada setiap warga negara untuk mendapatkan pengetahuan tentang lingkungan, serta cara untuk mengaplikasikannya dalam kehidupan sehari-hari. Pemberian konsep Enviromental citizenship melalui pendidikan kewarganegaraan akan membangun kesadaran siswa dalam kehidupan bermasyarakat tentang pentingnya menjaga lingkungan, serta menyadarkan tentang kewajiban dan tanggung jawabnyaa sebagai individu dalam masyarakat (Dobson 2007).

Apabila telah terbentuk kompetensi ekologi dalam diri siswa sekolah dasar, maka, akan terbentuk pula keterampilan siswa dalam menjaga lingkungannya,seperti keterampilan dalam menggunakan dan memanfaatkan sumber daya, keterampilan untuk melestarikan lingkungan, keterampilan dalam menghadapi masalah lingkungan hidup, dan keterampilan untuk bertanggung jawab terhadap lingkungannya. Menurut Muhaimin (2015), bahwa keterampilan dalam pelestarian lingkungan, ialah kesadaran yang dimiliki oleh manusia untuk menyeimbangkan kelestarian dan kebutuhan hidupnya untuk menciptakan kondisi lingkungan yang baik. Kecerdasan dan keterampilan ekologis dapat dilihat dari sikap siswa dalam memperlakukan lingkungan sekolahnya berdasarkan pengetahuan yang dimilikinya, seperti dapat bertindak secara spontan apabila melihat keran air yang terbuka, melihat sampah dan

Vol. 13 No. 2 Juni 2021

Madrasah homepage: http://ejournal.uin-malang.ac.id/index.php/madrasah/index 


\section{MADRASAH}

Jurnal Pendidikan dan Pembelajaran Dasar

p ISSN: 1979-5599 | e ISSN: 2502-194X

P a g e | 179

lain sebagainya (Rusmiyati, Noviana, \& Zufriady, 2019).

Terbentuknya keterampilan ekologi merupakan ciri dari terbentuknya kecerdasan ekologi. Kecerdasan ekologi merupakan kemampuan yang dimiliki oleh individu untuk berinteraksi dengan lingkungannya, serta mampu membentuk, mengatur, menjaga dan memanfaatkan lingkungannya untuk kepentingan bersama (Rusmiyati et al., 2019). Pada proses pengembangan materi pembelajaran yang dapat mengeskplor kompetensi ekologis siwa, guru sebaiknya memerhatikan kompenen dalam pengembangan pembelajaran seperti, pengembangan materi tidak hanya pada pengembangan kemampuan kongnitif saja, mengembangkan pembelajaran dengan materi berbasis ekopedagogik yaitu pengembangan materi yang tidak bersifat tekstual, kemudian pembelajaran haruslah berorientasi pada keikutsertaan siswa dalam proses pemecahan masalah lingkungan dan pendekatan yang digunakan memiliki output yang meaningfull terhadap proses pembelajarannya (Yunansah \& Tri Herlambang, 2017).

\section{b. Hubungan Kompetensi Ekologis dengan PKn}

Hubungan pendidikan kewarganegaraan dengan kompetensi ekologis dapat dilihat dari pandangan (Karatekin, K., \& Uysal, 2018) dalam penelitiannya tentang ecological citizenship scale development study yang mengatakan bahwa negara harus melakukan upaya melalui pendidikan untuk memastikan bahwa kegiatan warga negara tidak hanya untuk mengembangkan kepentingan perekonomian saja, tetapi juga menggunakan konsep perekonomian yang melindungi kelestarian alam. Sehingga melalui pernyataan tersebut, bahwa PKn merupakan sarana terencana dan sistematis yang dilakukan oleh pemerintah dalam mewujudkan tatanan lingkungan yang baik. Usaha tersebut dilakukan melalui proses integrasi kompetensi ekologi kedalam pendidikan kewarganegaraan. Pembentukan karakter lingkungan menjadi tujuan utama dalam hal ini, sehingga peran PKn di sini sangat signifikan.

Objek kajian PKn pada dasarnya tidak hanya berfokus pada persoalan politik, HAM dan sejarah pembentukan Indosia, tetapi juga berfokus pada pengembangan kompetensi warga negara yang memiliki karakter bertanggung jawab terhadap lingkungannya sebagai bentuk apresiasinya terhadap negaranya (Sundawa, Fitriasari, \& Iswandi, 2018). Pelestarian lingkungan, perlu dilakukan oleh guru dalam sekolah, keluarga dan masyarakat. Sesuai dengan kajian penelitian ini, bahwa pembentukan karakter melalui pola pembiasaan usia sekolah dasar dapat menjadi kebiasaan yang baik untuk mempersiapkan warga negara yang sadar lingkungan. Dalam penelitian ini, selain bertujuan untuk memperkuat kompetensi ekologi siswa, juga bertujuan untuk membentuk siswa menjadi warga negara yang melek lingkungan, cinta keindahan dan dapat bertanggung jawab atas lingkungannya. Sehingga menurut Beck \& Ritter (Dobson 2013) mengatakan bahwa "PKn memerlukan konsep baru untuk menjawab persoalan lingkungan sesuai perspektif $\mathrm{PKn}^{\prime \prime}$. Oleh karena itu, cakupan kajian PKn perlu diperluas pada isu lingkungan dunia (global citizen).

Dampak dari ketidakpahaman konsep pendidikan ekologi sejak dini akan memicu permasalahan sosial dan lingkungan, sehingga fokus masalahnya dapat disebabkan oleh perilaku manusia. Melalui hal ini, perlu adanya alat penunjang yang tidak hanya merusak lingkungan tetapi juga membantu dalam melestarikan dan melindungi lingkungan (Dobson 2013). Kaitannya dengan PKn yang selanjutnya ialah, warga negara menjadi pelaku utama dalam pemeliharaan lingkungan. Sehingga

Vol. 13 No. 2 Juni 2021

Madrasah homepage: http://ejournal.uin-malang.ac.id/index.php/madrasah/index 
apabila manusia sebagai individu telah memahami konsep pelestarian dan telah mampu berinteraksi dengan baik dengan lingkungannya, maka kemampuan ini telah menjawab kriteria keterampilan pelestarian lingkungan.

Selain itu pemberian pendidikan ekologi melalui PKn juga melatih siswa sekolah dasar untuk patuh terhadap nilai. Sehingga Nash (2018) mengatakan bahwa setiap individu memiliki nilai untuk membentuk tanggung jawab untuk dirinya dan lingkungannya. Kembali pada teori Dobson bahwa konsep ecological citizenship pada persoalan lingkungan, tidak hanya menyangkut persoalan individu tetapi juga merupakan tugas bersama dalam menjawab persoalan tersebut, individu yang memiliki keterampilan ekologis dapat memberikan pengaruh kepada individu lainnya, sehingga berbentuk kelompok, dan kelompok tersebut dapat mendesak pengampu pembuat kebijakan politik untuk ikut serta dalam melestarikan lingkungan (Valencia, M. \& J.A. Arroyave, R. Laberry, 2015).

Kemudian dalam temuannya, Dobson (2013) menganalisis bahwa terdapat dua pendekatan dalam menumbuhkan kesadaran lingkungan masyarakat. Pendekatan pertama ialah tentang perumusan suatu kebijakan, kedua melalui pendekatan pendidikan yang mengintegrasikan unsur kelestarian lingkungan ke dalam mata pelajaran Pendidikan Kewarganegaraan. Penanaman pendidikan lingkungan melalui dua cara ini dapat membentuk perilaku patuh warga negara, serta timbulnya naturalisasi kesadaran menjaga lingkungan langsung pada pribadi warga negara. Kerr, (2013) mengatakan bahwa pergerakan arah kajian Pendidikan Kewarganegaraan perlu diarahkan kepada urgensi masyarakat, yang mengarahkan kepada civic education yang memberikan nilai kepada warga negara dalam segala usia, sehingga kompetensi kewarganegaraan tentang ekologis akan dapat terlaksana dengan baik.

Bart dalam teorinya mengatakan bahwa lingkungan hidup pada dasarnya merupakan hak dasar yang dimiliki oleh warga negara. Sehingga hak itu tidak hanya mencakup hak sosial dan sipilnya saja tetapi juga hak dalam menikmati lingkungan. Selanjutnya dalam usaha Pendidikan Kewarganegaraan dalam melestarikan lingkungan, menurut analisis peneliti dilakukan melalui penguatan karakter lingkungan di sekolah, yaitu yang bersumber pada 18 nilai karakter yang diatur oleh pemerintah. Kemudian karakter peduli lingkungan tersebut diintegrasikan ke dalam perangkat pembelajaran seperti RPP, silabus dan lain-lain. Sementara dalam tulisannya Curtin (2014) perlindungan tentang hak warga negara tidak hanya berbicara soal perlindungan politik saja tetapi juga berkaitan dengan adanya kebijakan lingkungan. Sehingga masalah lingkungan dan politik merupakan dua masalah yang kompleks yang memerlukan penanganan yang serius. Apabila adanya perlindungan lingkungan maka akan terbentuknya etika dan moral. Berdasarkan pernyataan diatas, dikenal dengan moral identity yaitu manusia yang memandang dan memperlakukan alam seperti manusia yang memiliki hak hidup. Pandangan tersebut akan mempengaruhi pola pikir warga negara terhadap suatu kebijakan politik, mereka akan mendesak pemerintah untuk menciptakan suatu kebijakan yang dapat melindungi lingkungan.

Kompetensi ekologis selain berdampak pada moral, namun etika dan kebijakan politik. Domain ekologis juga merupakan salah satu bagian dalam program pendidikan kewarganegaraan untuk memberikan edukasi kepada masyarakat untuk melindungi lingkungan (Sapriya, 2015). Kompetensi ekologis juga mendorong warga negara untuk terlibat secara aktif, baik dalam proses pengambilan keputusan maupun dalam proses penjagaan lingkungan, hal ini disebut sebagai program pendidikan kewarganegaraan

Vol. 13 No. 2 Juni 2021

Madrasah homepage: http://ejournal.uin-malang.ac.id/index.php/madrasah/index 


\section{MADRASAH}

Jurnal Pendidikan dan Pembelajaran Dasar

p ISSN: 1979-5599 | e ISSN: 2502-194X

P a g e | 181

sisio kultural (Winataputra 2015). Peran guru dalam membentuk warga negara yang memiliki karakter lingkungan, maka tolak ukur pendapat ini ialah adanya pernyataan Cogan (1988) yang mengatakan bahwa, tujuan pendidikan kewarganegaraan diajarkan pada jenjang persekolahan khususnya sekolah dasar ialah untuk membentuk dan mempersiapkan warga negara yang bertanggung jawab dan partisipatif pada dirinya, bangsa dan negaranya. Sehubungan dengan hal itu, dapat disimpulkan bahwa tolak ukur keberhasilan pembentukan karakter lingkungan anak dapat dilakukan pada usia dini, melalui pendidikan formal dan non formal. Perubahan karakter yang terdapat pada pribadi anak lebih besar karena mendapatkan sentuhan pendidikan (Budimansyah, 2012). Oleh karena itu, visi dalam melahirkan kompetensi ekologis atau ecologis citizenship melalui pendidikan kewarganegaraan perlu dilakukan sesuai perspektif pendidikan kewarganegaraan.

Untuk melihat apakah siswa dapat mengaplikasikan pengetahuan ekologi yang dimilikinya dalam kehidupan sehari-hari, maka perlu dikaji berdasarkan teori kontruktivisme yaitu teori yang mengkontuksikan pengetahuan yang dimilikinya dalam kehidupannya sehari-hari (Sanjaya, 2008). Maka untuk mendapatkan harapan seperti yang sudah dijelaskan di atas, hal ini ditentukan oleh bagaimana guru menerapkan startegi dan model pembelajaran yang membekas pada peserta didik, maka model pembelajaran yang digunakan sebaiknya ialah model yang meaningfull dan berbasis pada project, sehingga melatih kemampuan nalar dan keterampilan peserta didik (Komalasari, 2013). Perencanaan pembelajaran yang di dalamnya sudah terintegrasikan oleh kompetensi ekologis merupakan suatu upaya dalam memberikan praktik kewarganegaraan yang dapat mengubah pandangan siswa terhadap pelestarian lingkungan, oleh karena itu melalui penelitiannya, Wolff (2009) mengatakan bahwa dalam pengintegrasian pembelajaran lingkungan hendaknya memasukkan kompetensi ekonom, komunitarian, sistemis untuk menjaga kelestarian lingkungan.

Terdapat beberapa penelitian yang memperkuat penelitian ini diantaranya, adanya penelitian Jagers, S. (2014) yang mengembangkan model pendidikan kewarganegaraan untuk lingungan hidup yang berbasis pada praktik dimasyarakat. Penelitian ini menjadi pelopor bahwa pelaksanaan pembelajaran tidak hanya bergantung pada peningkatan pengetahuan saja, tetapi juga harus difokuskan kepada praktik siswa dalam masyarakat. Selanjutnya penelitian oleh Budimansyah dan Prasetyo tentang praktik PKn dalam konteks sosio kultural melalui komunitas perlindungan lingkungan dapat berdampak pada terbentuknya kebaikan pada warga negara. Sehingga dari pelaksanaan kegiatan tersebut dapat menjadi role model untuk menumbuhkan kesadaran lingkungan pada warga negara

Sehingga untuk memperkuat penemuan peneliti, terdapat penelitian yang dilakukan oleh Indriyana dan Yoga tentang Konfigurasi Pendidikan Kewarganegaraan Ekologi Perspektif sosio-kultural (Gagasan Pembentukan Pendidikan Kewarganegaraan Kontium Maksimal di Indonesia) yang menghasilkan bahwa pendidikan kewarganegaraan ekologi dapat dilakukan dengan konsep cooperatif citizenship membentuk tanggung jawab warga negara sebagai individu dan community civic (Dwi Mustikarini \& Feriandi, 2020). Sehingga perbedaan dalam penelitian ini ialah, penelitian ini berusaha mengkaji dan menganalisis tentang kompetensi warga negara melalui pendidikan ekologi yang diintegrasikan kedalam pendidikan

Vol. 13 No. 2 Juni 2021

Madrasah homepage: http://ejournal.uin-malang.ac.id/index.php/madrasah/index 
kewarganegaraan, sebagai salah satu bentuk usaha dalam menciptakan warga negara yang melek lingkungan, warga negara ekologis dan bertanggung jawab terhadap lingkungannya.

\section{KESIMPULAN}

Sesuai dengan tujuan dan rumusan masalah dalam penelitian ini, maka dapat ditarik kesimpulan bahwa, dalam usaha untuk membentuk kompetensi ekologi siswa sekolah dasar melalui pendidikan kewarganegaraan ialah dapat dilakukan melalui proses integrasikan kompetensi ekologis kedalam perangkat pembelajaran PKn seperti RPP, silabus dan lain-lain. Kemudian dalam rangka meningkatkan praktik kompetensi ekologis siswa, guru sebaiknya menggunakan model pembelajaran yang meaningfull dan berbasis pada project untuk membentuk partisipasi dan keikutsertaan siswa dalam proses pembelajaran. Selain itu, guru dapat menciptakan karakter lingkungan atau ecologis citizenship melalui pengintegrasian materi pembelajaran yang dapat menumbuhkan kompetensi ekologis pada pembelajaran PKn, yaitu dengan memberikan contoh pelaksanaan mereka dalam kehidupan sehari-hari. Sehingga siswa tidak hanya paham secara materi saja tetapi mampu mengaplikasikannya dalam kehidupan sehari-hari.

Selain itu sesuai dengan tujuan dari pendidikan kewarganegaraan maka kompetensi ekologis dapat terbentuk melalui pola pembiasaan yang diberikan oleh guru kepada siswa, adapun kompetensi yang dihasilkan ialah, pertama kompetensi pengetahuan tentang isu lingkungam, kedua siswa memiliki startegi untuk menyusun tindakan terhadap isu lingkungan, dan yang ketiga siswa dapat bertindak secara dewasa terhadap isu lingkungannya. Apabila siswa sudah memahami dengan baik konsep melestarikan lingkungan melalui pembelajaran PKn di sekolah, maka akan terbentuknya kecerdasan lingkungan atau keterampilan lingkungan. Keterampilan ini diantaranya ialah keterampilan memanfaatkan lingkungan, berinteraksi dengan lingkungan, dan keterampilan untuk bertanggung jawab terhadap sumber daya yang ada. Sehingga dalam hal ini, PKn memiliki peran penting dalam melahirkan konsep pembelajaran yang baru yang dapat melahirkan siswa sebagai warga negara yang bertanggung jawab dan memiliki karakter lingkungan atau ecologis citizenship.

\section{REFERENSI}

Berkowitz, A. R., Ford, M. E., \& Brewer, C. A. (2005). A framework for integrating ecological literacy, civics literacy, and environmental citizenship in environmental education. In E. Johnson, E. A. Johnson, \& M. J. Mappin (Eds.), Environmental education and advocacy: Changing perspectives of ecology and education (pp. 227-266). Cambridge University Press.

Budimansyah, D. (2012). Penguatan Pendidikan Kewarganegaraan Untuk Membangun Karakter Bangsa. Bandung: Widya Aksara Press.

Budimansyah, D., Fitriasari, S., Iswandi, D., Muthaqin, D. I., \& Insani, N. N. (2021). Green Constitution: Developing Environmental Law Awareness. Proceedings of the 2nd International Conference on Social Sciences Education (ICSSE 2020), 525(Icsse 2020), 200-204. https:// doi.org/10.2991/assehr.k.210222.031

Cogan. (1988). Citizethnship Education for the 21st Century: Setting the Context. London:

Vol. 13 No. 2 Juni 2021

Madrasah homepage: http://ejournal.uin-malang.ac.id/index.php/madrasah/index 


\section{MADRASAH}

Jurnal Pendidikan dan Pembelajaran Dasar

p ISSN: 1979-5599 | e ISSN: 2502-194X

P a g e | 183

Kogan Page Ltd.

Cogan, J. J. (1983). Citizenship Education for the 21st Century: Setting the Context. Dalam J.J.

Cogan \& R. Derricot. London: Kogan Page Limited.

Creswell, J. W. (2016). Research Design : Pendekatan Metode Kualitatif, Kuantitatif dan

Campuran. Edisi Keempat (cetakan kesatu). Yogyakarta: Pustaka Belajar.

Curtin. (2014). The Miopia. Philadelphia Harper E Row, 348-381.

Danial, E., \& Wasriah. (2009). Metode Penulisan Karya Ilmiah. Bandung: Laboratorium

Pendidikan Kewarganegaraan UPI.

Dobson, A. (2007). Environmental citizenship: towards sustainable development.

Sustainable Development, 15(5), 276-285.

Dobson, Andrew. (2007). Environmental Citizenship : Towards Sustainable

Development. Sustainable Development, 285(15), 276-285.

https://doi.org/10.1002/sd.344

Dwi Mustikarini, I., \& Feriandi, Y. A. (2020). Konfigurasi Pendidikan Kewarganegaraan

Ekologi Perspektif sosio-kultural (Gagasan Pembentukan Pendidikan

Kewarganegaraan Kontium Maksimal di Indonesia). Pancasila Dan

Kewarganegaraan, 5 nomor 2, 54-64. https:/ / doi.org/10.24269/jpk.v5.n2.2020.pp5464

Feriandi, Y. A. (2018). Upaya perlindungan Lingkungan Perspektif Konstitusi dan Pendidikan Kewarganegaraan. Pancasila Dan Kewarganegaraan, JI 3 (2).

Jagers, S, C. (2014). In search of the ecological citizen. Environmental Politics: Taylor $\mathcal{E}$ Francis. 18 No 1. https:/ / doi.org/10.1080/09644010802624751.

Karatekin, K., \& Uysal, C. (2018). Ecological citizenship scale development study. International Electronic Journal of Environmental Education, 8 nomor 2, 82-104.

Karatekin, K., \& Uysal, C. (2018). Ecological citizenship scale development study. International Electronic Journal of Environmental Education, 8(2), 82-104.

Karsten, S., et al. (1998). Challenges Facing The 21St Century Citizen: Views of Po_licy Makers", dalam Cogan, JJ dan Der_ricot, R. (eds.), Citizenship for The 21st Challenges Facing The 21St Century Citizen: Views of Po_licy Makers", dalam Cogan, JJ dan Der_ricot, R. (eds.), Citize. London: Kogan Page Limit- ed.

Kerr, D. (2013). Citizenship education in the curriculum. An International Review. School Field, 10 (3/4), 5-32.

Komalasari, K. (2013). Pembelajaran Kontekstual (ketiga; nurul falah, ed.). Bandung: PT. Refika Aditama.

Krasny, M. E., Silva, P., Barr, C., Golshani, Z., Lee, E., Ligas, R., ... Reynosa, A. (2015). Civic ecology practices : insights from practice theory. 20(2).

Latta, P. A. (2007). Locating democratic politics in ecological citizenship Locating Democratic Politics in Ecological Citizenship. (November 2012), 37-41.

https://doi.org/10.1080/09644010701251631

McBride, B. B., Brewer, C. A., Berkowitz, A., \& R., \& Borrie, W. T. (2013). Environmental literacy, ecological literacy, ecoliteracy: what do we mean and how did we get here? Ecosphere. 4 (5), 1-20.

Muhaimin. (2015). Manajemen Pendidikan Aplikasinya Dalam Penyusunan Rencana Pengembangan Sekolah/Madrasah. Jakarta: Kencana Prenada Media Group.

Mulyasa. (2014). Pengembangan dan Implementasi Kurikulum 2013. Bandung: Remaja

Vol. 13 No. 2 Juni 2021

Madrasah homepage: http://ejournal.uin-malang.ac.id/index.php/madrasah/index 
Rosdakarya.

Nash, T. H. (2018). Lichen Biology Second Edition. New York: Cambridge University Press.

Palmer, J. A. (2015). Environmental Education in the 21st Century: Theory, Practice, Progress and Promise. London: Routledge.

Pertiwi, S., \& Samsuri. (2017). Pembentukan kompetensi ekologis dengan model pembelajaran kontekstual dan berbasis masalah dalam PPKn di SMP. Civics, 14 Nomor 2. https:/ / doi.org/https:/ / doi.org/10.21831/civics.v14i2.14972

Quinn, F., Castéra, J., \& Clément, P. (2016). Teachers' conceptions of the environment: anthropocentrism, non-anthropocentrism, anthropomorphism and the place of nature. Environmental Education Research, 22(6), 893-917.

https:/ / doi.org/10.1080/13504622.2015.1076767

Rusmiyati, T., Noviana, E., \& Zufriady. (2019). Analisis Kecerdasan Ekologis Siswa Sekolah Dasar Di SD Negeri 147 Pekanbaru (Studi Di Kelas Tinggi SDN 147 Pekanbaru. JURNAL PENDIDIKAN GURU SEKOLAH DASAR, 8 Nomor 1. https://doi.org/http://dx.doi.org/10.33578/jpfkip.v8i1.6744

Sagala, R., Nuangchalerm, P., Saregar, A., \& El Islami, R. A. Z. (2019). Environmentfriendly education as a solution to against global warming: A case study at Sekolah Alam Lampung, Indonesia. Journal for the Education of Gifted Young Scientists, 7(2), 85-97. https:/ / doi.org/10.17478/jegys.565454

Sanjaya, wina. (2008). Strategi pembelajaran berorientasi standar proses pendidikan. Jakarta: Kencana Prenada Media Group.

Sapriya. (2015). Pendidikan IPS. Bandung: Remaja Rosdakarya.

Scoville, C. (2016). George Orwell and ecological citizenship: moral agency and modern estrangement. Citizenship Studies, 20(6-7), 830-845. https://doi.org/10.1080/13621025.2016.1192105

Snyder, H. (2019). Literature review as a research methodology: An overview and guidelines. Journal of Business Research, 104(July), 333-339. https://doi.org/10.1016/j.jbusres.2019.07.039

Sukma, E., Ramadhan, S., \& Indriyani, V. (2020). Integration of environmental education in elementary schools. Journal of Physics: Conference Series, 1481(1). https://doi.org/10.1088/1742-6596/1481/1/012136

Sundawa, D., Fitriasari, S., \& Iswandi, D. (2018). Sustainable Development Principles in the Green Constitution. IOP Conference Series: Earth and Environmental Science, 145(1). https://doi.org/10.1088/1755-1315/145/1/012122

Thomas Lickona. (2012). educating for character : how our schools can teach respect and responsibility (1st ed.; uyu Wahyudin, ed.). Jakarta: PT. Bumi Aksara.

Valencia, M., \& J.A. Arroyave, R. Laberry, C. L. (2015). Study on transmission on the causal agent of the cassava witches'broom. Fitopatologia, 17 (1-2), 39-45.

Valencia Sáiz, A. (2005). Globalisation, cosmopolitanism and ecological citizenship. Environmental Politics, 14(2), 163-178. https:/ / doi.org/10.1080/09644010500054848

Wahab, abdul, \& Sapriya. (2011). Teori dan Landasan Pendidikan Kewarganegaraan (1st ed.; riduwan, ed.). Bandung: PT. Alfabeta Cv.

Wahyuningtiyas, N. (2016). Evaluasi Sikap Dan Perilaku Siswa Terhadap Lingkungan Hidup Dan Pembangunan Berwawasan Lingkungan Di Madrasah. Madrasah, 6(1), 8. https:/ / doi.org/10.18860/jt.v6i1.3290

Winataputri, U. (2015). Strategi Belajar Mengajar. Jakarta: Pusat Penerbitan Universitas

Vol. 13 No. 2 Juni 2021

Madrasah homepage: http://ejournal.uin-malang.ac.id/index.php/madrasah/index 


\section{MADRASAH}

Jurnal Pendidikan dan Pembelajaran Dasar

p ISSN: 1979-5599 | e ISSN: 2502-194X

Terbuka.

Wolf, J., Brown, K., \& Conway, D. (2009). Ecological citizenship and climate change:

Perceptions and practice. Environmental Politics, 18(4), 503-521.

https://doi.org/10.1080/09644010903007377

Wolff. (2009). Fitzpatrick's Color Atlas and Synopsis of Clinical Dermatology: Candidiasis. New York: Mc Graw Hill Companies.

Yunansah, H., \& Tri Herlambang, Y. (2017). Pendidikan Berbasis Ekopedagogik Dalam Menumbuhkan Kesadaran Ekologis Dan Mengembangkan Karakter Siswa Sekolah Dasar. Pendidikan Dasar | ISSN 2085-1243, 9 nomor 1, 27-34.

https://doi.org/https:/ / doi.org/10.17509/eh.v9i1.6153

Zhang, X., Tan, J., \& Chan, K. C. (2020). Environmental law enforcement as external monitoring: Evidence from the impact of an environmental inspection program on firm-level stock price crash risk. International Review of Economics $\mathcal{E}$ Finance, 71(July 2020), 21-31. https://doi.org/10.1016/j.iref.2020.08.020 